\title{
Indian National Strong Motion Instrumentation Network and Site Characterization of Its Stations
}

\author{
Himanshu Mittal, Ashok Kumar, Rebecca Ramhmachhuani \\ Department of Earthquake Engineering, Indian Institute of Technology, Roorkee, India \\ Email: himanshumitt10@gmail.com
}

Received August 21, 2012; revised September 23, 2012; accepted October 21, 2012

\begin{abstract}
Indian Institute of Technology, Roorkee (IITR) is operating a nationwide network of instruments for recording strong ground motion. Total 300 instruments are installed in seismic zone III, IV and V along Himalayan belt. Primary goal of this project is to acquire strong ground-motion (SGM) data for various studies in the field of earthquake engineering and seismology in general and in particular to understand propagation and site response characteristics of the sediments that underlie and are thought to produce large site amplification and seismic hazard. These data will complement laboratory data to characterize the properties of the soft soils underlying residential area so that engineers and architects can design appropriate earthquake-resistant structures for the region. The successful working of this network has laid the foundation of Earthquake Early Warning System (EEW) in India. A great number of strong motion records have been obtained and utilized to study local site and geological effects. The paper introduces outline of the IITR strong motion network and some of its recent studies.
\end{abstract}

Keywords: IITR; Amplification; SGM; Accelerographs; Earthquake; EEW

\section{Introduction}

Strong motion seismographs are instruments designed to record the time history of strong ground motions where the traditional high-gain seismographs used to routinely locate earthquakes go off scale. They are often called accelerographs because they measure acceleration of the ground. Ground motion time-histories recorded during past earthquakes in a region provide valuable information about the expected characteristics of ground motion at a site during a future earthquake in that region. These records are essential for evaluating earthquake resistant design procedures, estimation of attenuation characteristics, assessment of seismic hazard and earthquake risk. Accordingly, analysis of strong ground motion data leads to a better understanding of the potential effect of strong shaking during earthquakes. The ground motion characteristics determined from strong motion records are studied in various terrain and rock conditions and have been related to various earthquake parameters. The analysis of data has also helped in understanding the soil-structure interaction, effects of soil deposits, topography and other effects.

More than half of the area of India is susceptible to strong ground motions from earthquakes; therefore it is essential to know about the probable characteristics of strong ground motion of future earthquakes in this region.
For earthquake engineering purposes, a number of different parameters are typically used to characterize strong motion records. These parameters include peak acceleration, peak velocity, peak displacement, duration of strong shaking, and response spectra. A rational assessment of the expected seismic hazard in different regions of the country will lead to substantial monetary savings in the design of structures and reduce potential losses from earthquakes.

India has a two-pronged earthquake problem. There is severe seismic hazard along the Himalayan belt and also at the western margin of the country in the state of Gujarat. IIT Roorkee is operating a network of 300 strong motion accelerographs in Himalayas and adjoining planes lying in seismic zomes V, IV and III of Indian seismic zoning map [1]. It is this network which is being discussed in detail in this paper. For monitoring earthquakes originating from Gujarat region, Indian Seismological Research (ISR) institute, Gandhinagar is operating a network of 43 strong-motion accelerographs [2].

The Indian plate pushes into the Asian plate at the high rate of 15 to $20 \mathrm{~cm} /$ year [3], and as a direct result of the collision between the Indian and the Asian plates the state of stress in the Indian plate is high, which in turn increases the earthquake hazard, particularly in northern India along the Himalaya collision zone. This process has given rise to three major thrust planes: (e.g., [4,5]) the 
Main Central Thrust (MCT), the Main Boundary Thrust (MBT), and the Main Frontal Thrust (MFT). The region has experienced several great earthquakes in the past hundred years or so (1897 Assam; 1905 Kangra; 1934 Bihar-Nepal; 1950 Assam). The Himalayan geodynamics and the occurrence of great earthquakes are well summarized by [6-8]. During the last episode of strain release, a 750-km-long segment, which lies between the eastern edge of the 1905 rupture zone and the western edge of the 1934 earthquake, remained unbroken (Figure 1). This segment, called the central seismic gap, continues to be under high strain [9]. Large earthquakes occurred in this seismic gap in 1803 and 1833, but the magnitudes of these earthquakes were less than 8 , and, hence, they were not gap-filling events $([10,11])$. Based on these considerations and on a shortening rate of $20 \mathrm{~mm} / \mathrm{yr}$ across the Himalayas ([3,12-14]), [7] has estimated the probability of occurrence of a great $\mathrm{Mw} 8.5$ earthquake in the gap in the next 100 yr to be 0.59 .

The northeastern region of India is also regarded as one of the most seismically active regions worldwide. A seismic gap called Northeast Seismic gap is there between the 1950 Assam earthquake and the $1934 \mathrm{Bi}$ har-Nepal earthquake (Figure 1), where no major earthquake occurred in recent time. The past seismicity data from 1897 shows that the northeastern region has experienced two great earthquakes with magnitudes above 8.0 and about 20 large earthquakes with magnitudes varying between 8.0 and 7.0 [15]. These devastating earthquakes occurred in northeastern India when population was 10 times less than at present; if such earthquakes were to occur in the near future, they would be much more devastating, thus emphasizing the need for

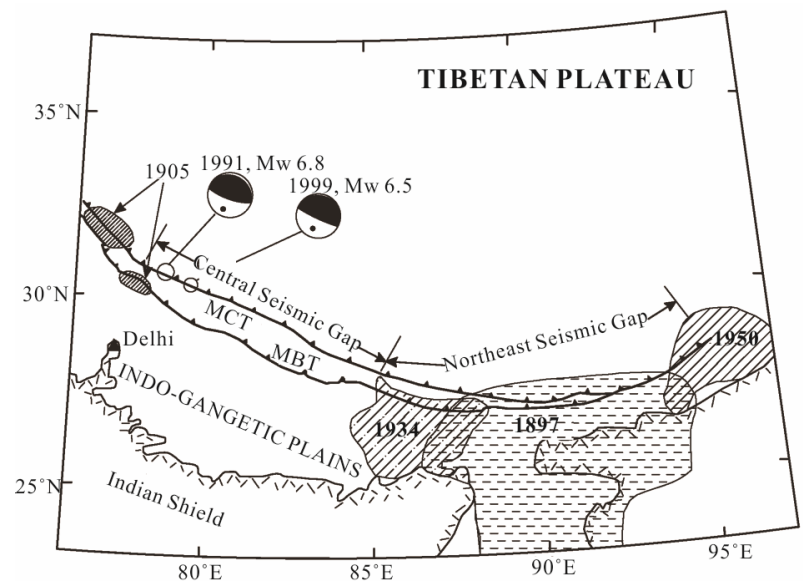

Figure 1. Tectonic map of the Himalayas. The different two seismic gaps are shown. The segment between the rupture areas of the 1905 and 1934 earthquakes is known as the central seismic gap and the segment between the rupture areas of the 1934 and 1950 earthquakes is known as the northeast seismic gap MCT, main central thrust; MBT, main boundary thrust (modified after [6]). seismic hazard estimation in north eastern India as well. Studies related to hazard estimation depend on the availability of strong ground motion records from past earthquakes.

The strong motion programme in India was started in mid-sixties when an analogue accelerograph named as RESA (Roorkee Earthquake School Accelerograph) and another low cost strong motion instrument known as the Structural Response Recorder (SRR) were developed at Department of Earthquake Engineering (DEQ). Initially these instruments were installed in some river valley projects like Bhakra, Pong, Talwara, Tehri, etc. Later, in 1976, a research project INSMIN (Indian National Strong Motion Instrumentation Network) was funded, on the recommendation of the Planning Commission, by Department of Science and Technology (DST), Government of India, for fabrication, installation, maintenance and operation of RESA-V and SRRs.

Further, on the recommendation of the International Association of Earthquake Engineering, funds were sanctioned by the National Science Foundation, U.S.A. in 1982 to DEQ for installation of an array of 50 analogue accelerographs in Shillong region of North-Eastern India from which fifty analogue accelerographs (imported) were installed. In 1986, through funding from DST about 50 instruments in Himachal Pradesh, about 40 in Western U.P. hills and about 30 instruments in Arunachal Pradesh, Assam and Bihar were installed [16]. All these instruments have now outlived their life and most of them are nonfunctional and unrepairable. However, during their life time this instrumentation has provided useful strong ground motion data which was disseminated and widely used for research.

Strong motion instrumentation programme in our country got big boost and was substantially strengthened in 2004 when DST sanctioned a project for installation of 300 strong motion accelerographs in this region [17]. Under this project, state of the art instruments were procured and successfully installed in different parts of country covering seismic Zone IV and V and some of the thickly populated areas of Zone III of seismic zoning map of India [1]. This network was further strengthened in 2007 when another project entitled "Strong Motion Instrumentation Network in Delhi" was sanctioned by DST to IITR. Under this project 20 digital strong motion accelerographs were installed in the Delhi region [18].

\section{Strong Motion Network and Performance}

The main objective of the seismic instrumentation is to record the ground motion arising due to natural and manmade disturbances and, in particular, to monitor the seismicity of a given region. This project is also a first step toward developing a "Rapid Response and Damage Prediction System” for India where near real-time strong 
ground-motion records can be used to compute groundshaking maps showing the area most strongly affected by earthquakes.

The Strong motion instrumentation network of IITR covers the Indian Himalayan range from Jammu and Kashmir to Meghalaya. In total, 298 strong motion stations have been installed in the states of Himachal Pradesh, Punjab, Haryana, Rajasthan, Uttarakhand, Uttar Pradesh, Bihar, Sikkim, West Bengal, Andaman and Nicobar, Meghalaya, Arunachal Pradesh, Mizoram and Assam. 20 instruments out of 298 are installed in Delhi, the national capital of India. Figure 2 shows location of stations of this network along the Himalayan belt while Figure $\mathbf{3}$

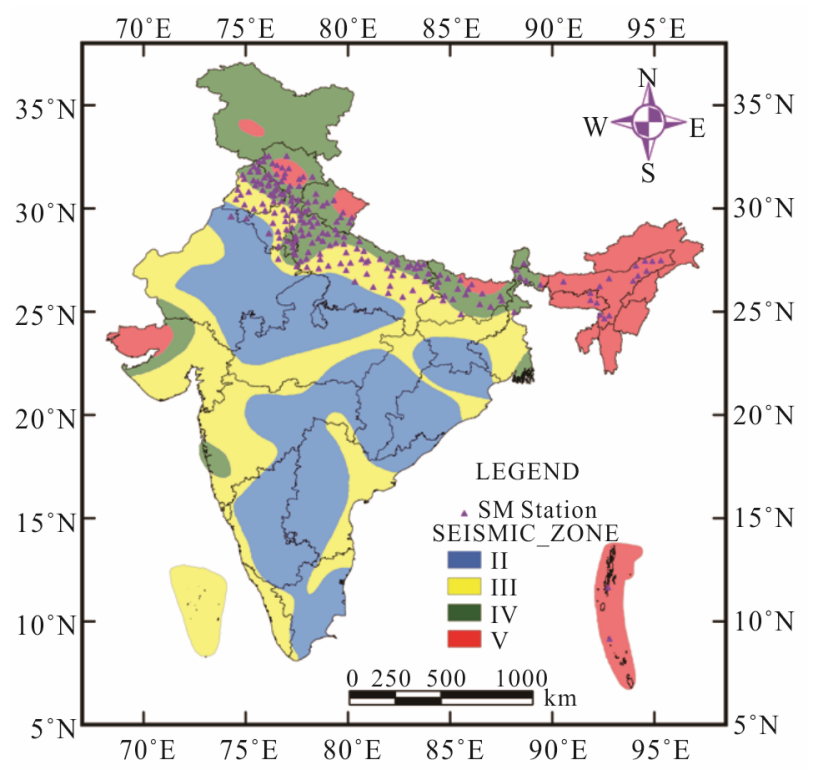

Figure 2. Map showing the location of instruments along the Himalayan belt.

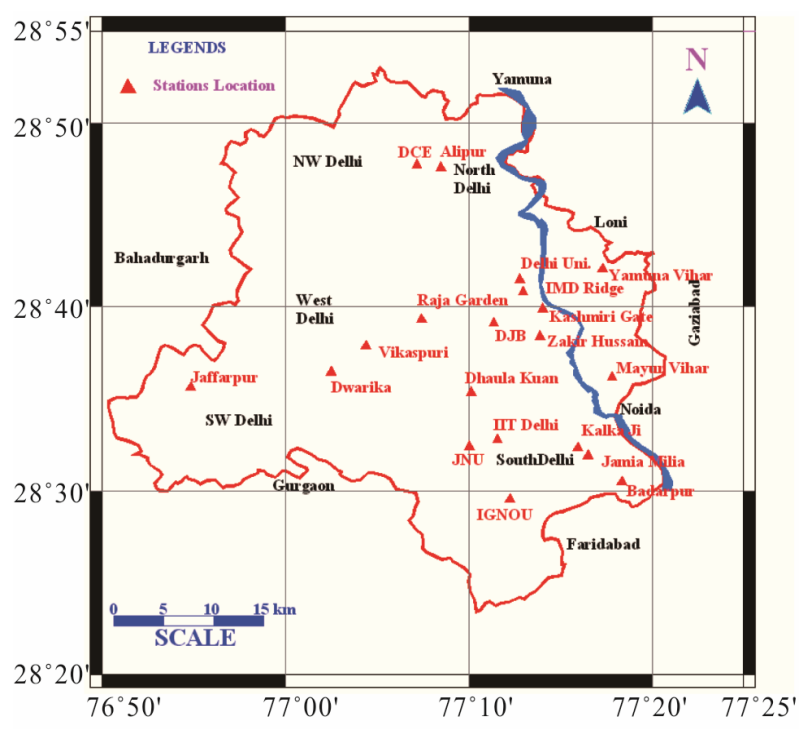

Figure 3. Map showing the location of instruments in Delhi. shows location of stations installed in Delhi. Appendixes $\mathbf{1}$ and $\mathbf{2}$ give location of these instruments as well as site characteristics of each station.

\subsection{Installation}

Seismic networks have been costly to install and maintain. A seismic station requires a sensor to record the ground motion, a computer to save the data, a GPS for accurate timing and location, V Sat/Lease line equipment to send the data back to a central processing house and a power source to run the equipment. Each seismic station is a self-contained system that can take several hours to install. While these stations provide high-quality, reliable data, currently costs and other factors prohibit increasing the density of stations over a large region such as India. Based on these, site selection for instrument installation has been generally a compromise between network geometry, logistics, and safe installation. The ground floor of one or two storied government owned buildings were marked for installation in order to ensure safety and $220 \mathrm{v}$ AC power supply. The average station to station spacing was decided to be $40-50 \mathrm{~km}$ in plains and less (25 - $35 \mathrm{~km})$ in hilly regions.

However, all 20 stations in Delhi have been installed in open space on a pedestal.

\subsection{Connectivity}

Networking of instrumentation has created capability of almost real time availability of strong ground motion data. More than 225 of these installations are connected for remote interrogation (from Roorkee) for health monitoring of instruments and data downloading using NICNET of National Informatic System (NIC) and State Wide Area Network (SWAN) of various states. Telecommunication links to the entire instrumentation is planned so that each instrument can be accessed from headquarter or from other remote locations. Data flows through VSAT/Leased line from these field stations to NIC headquarters in Delhi. From Delhi to Roorkee data flows on a 2 MBPS leased line of Bharat Sanchar Nigam Limited (BSNL) (Figure 4). All the twenty installations of Delhi are connected to Roorkee through the MahaNagar Telephone Nagar Limited (MTNL) network.

\subsection{Instrumentation}

All the strong-motion accelerographs (except 12 in Delhi) consist of internal AC-63 GeoSIG triaxial forced balance accelerometers based on the latest Micro Electro-Mechanical Systems (MEMS) technology with a dynamic range of $>120 \mathrm{~dB}$ effective at $\pm 3 \mathrm{~g}$ full scale and band width DC to $100 \mathrm{~Hz}$. All accelerographs have GSR-18 GeoSIG 18-bit digitizers with external GPS. The GSR-18 Strong Motion Recorder has a dynamic range of $111 \mathrm{~dB}$ 
@100 SPS and 108 dB @200 SPS. The standard 3 channel system has selectable sampling rates from 100 to 250 SPS. A variety of sensors can be connected to the GSR18 offering solutions for applications in miscellaneous fields. Geodas software developed by GEOSIG is used for communicating with instruments installed in field. GeoDAS is a graphical Microsoft Windows-based application running under Windows 2000/XP/Vista/7. Figure 5 shows the setup of instruments in field.

The 12 strong motion accelerographs installed in Delhi are K-2 (Kinemetrics K-2s) with internal accelerometer (model Episensor) and 18-bit digitizer. The recording for all instruments is in trigger mode at a sampling frequency of 200 sps. The triggering threshold was initially set at $0.005 \mathrm{~g}$ for all the instruments. Later on threshold was reduced to $0.002 \mathrm{~g}$ for instruments installed in hilly region (i.e. Himachal Pradesh, Uttarakhand and some part of northeast) and 0.001 for all instruments installed in Delhi. The recording is done on a 256-MB GeoSIG or 1-GB Kinemetrics compact flash card.

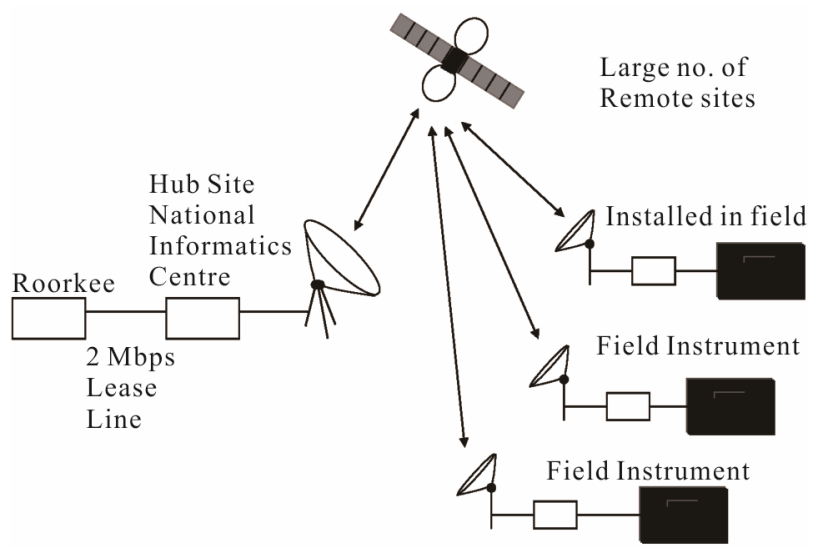

Figure 4. A diagram showing the networking of instruments installed in field to Roorkee (the central station).

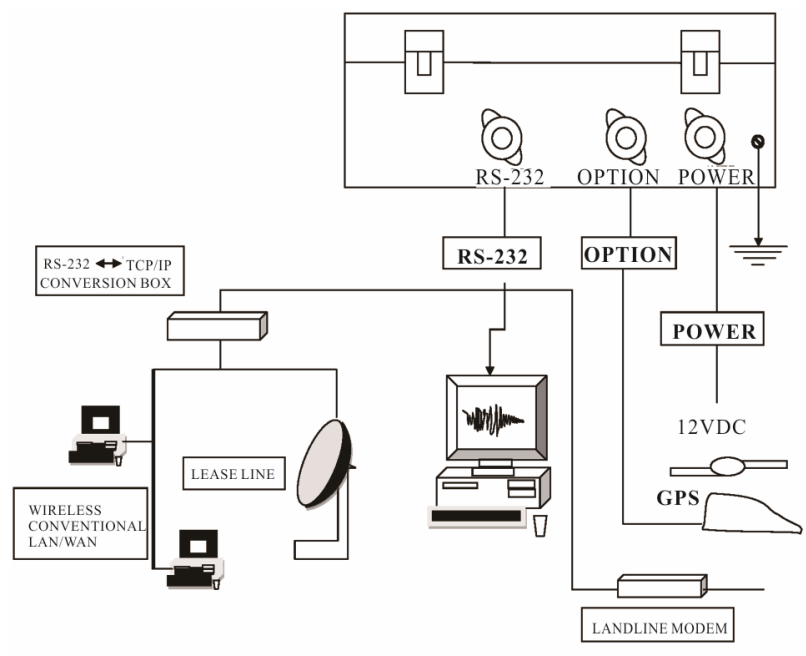

Figure 5. A figure showing the setup of instruments in field.
Each seismic station is powered by external 12-volt batteries with regular charging through a 220 volts alternating current (VAC) line. The health of the instruments is monitored routinely by connecting instruments twice/ thrice a day. The central recording station at the IIT receives seismic data from all 298 seismic stations. There are four servers to receive the data, each having approximately 75 stations connected.

\subsection{Objectives}

Since there is considerable gap between the occurrence of moderate to strong earthquakes it is essential that the instruments are maintained in long term basis. As a result maintenance of strong motion instruments installations in the field becomes very important task. The main goals of the project are both to collect data with a wide range of magnitude, thus allowing us to increase knowledge of the Himalayan area; and to assure the recovery of high quality datasets in cases of strong events. Strong ground motion records during earthquakes provide the basic information for earthquake engineering. These records are input for evaluation of attenuation characteristics and seismic hazard of an area, in perfecting design practices and eventually the basics of earthquake engineering research. The analysis of data from this network will help in validating existing attenuation relationship and making attenuation relationship and/or neural network model most suitable for our country. Advancement in communication in our country has substantially enhanced the importance of strong motion instrumentation network. In future, this network should not only generate crucial data set for ground motion studies but should provide almost real time ground motion scenario immediately after major events which will be of great value for disaster management. Further development of this instrumentation should lead to earthquake early warning system, a dream which is well within our grasp.

\subsection{Achievements}

The IIT network is equipped with all the latest seismic instruments, and quality seismic data are being produced that will be very helpful in seismological/engineering research. This instrumentation network has recorded around 180 earthquakes in a span of 5 years. Several prominent earthquakes in the Northern Himalayas as well as in the Northeast Himalayas were recorded. Records were obtained for near-source earthquakes at distances of $10 \mathrm{~km}$, and for a far-source earthquake at a distance of $1350 \mathrm{~km}$. Figure 6 shows example of a strong motion accelerograph record from the $M w$ 6.8 Sikkim-Nepal Border region earthquake that occurred on 18 September 2011, and Figure 7 shows a strong motion accelerograph record from the $M w$ 7.4 Southwestern Pakistan earthquake 

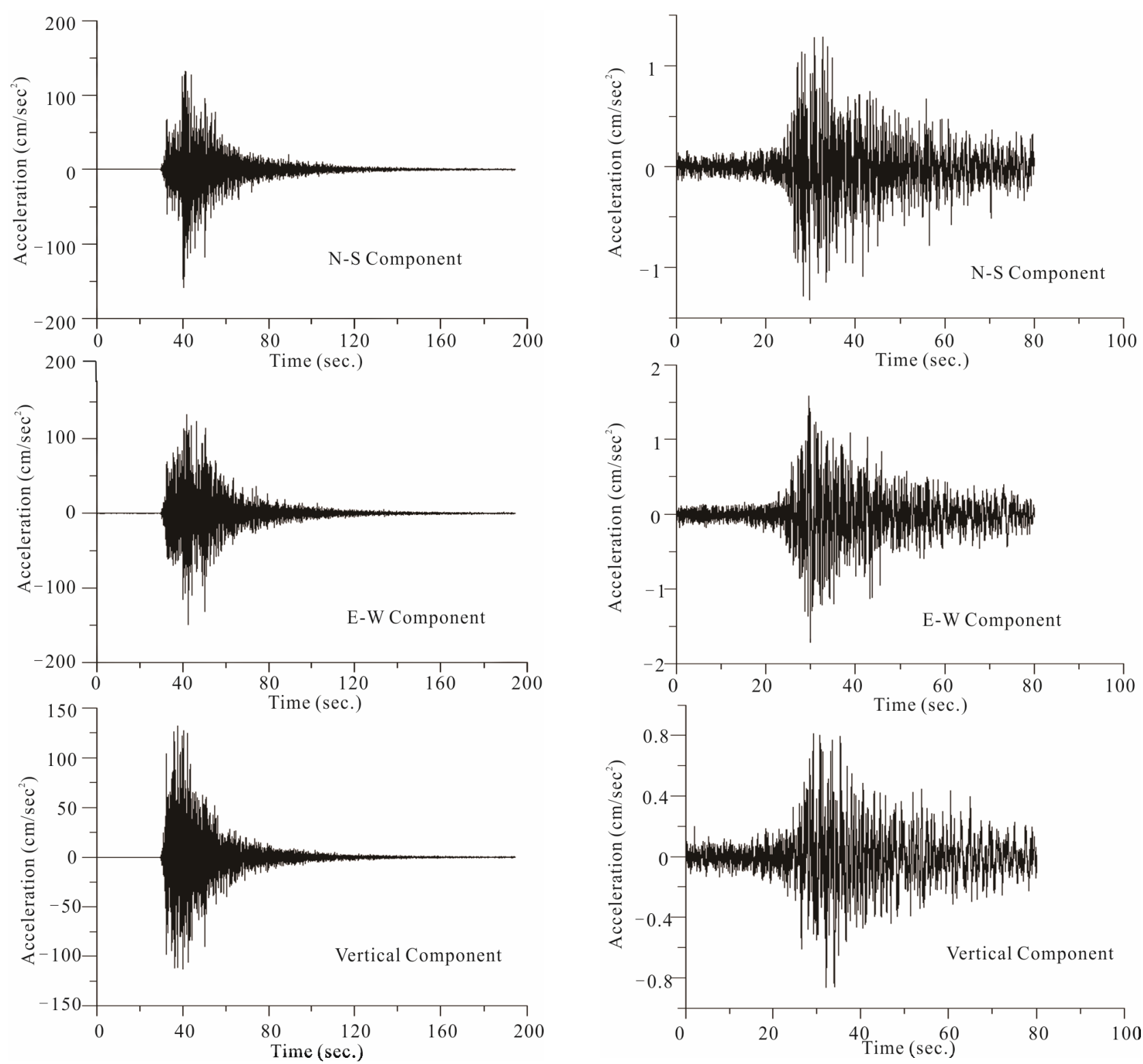

Figure 6. A sample strong motion record of an $M w 6.8$ earthquake from the Sikkim-Nepal border region recorded at the Gangtok station (epicentral distance $58 \mathrm{~km}$ ) on 18 September 2011.

that occurred on 18 January 2011.

\subsection{Data Processing}

Presently, all data processing is carried out in offline mode on different softwares. All downloaded accelerograms are processed before dissemination. Data is processed using two different computer programs for Geosig and Kinemtrics record [18]. In general, both computer programs read headers of ASCII files of records, generate the output header, baseline correct the record, and rotate the horizontal components to get N-S and E-W components.

Figure 7. A sample strong motion (Geosig) record of an $M w$ 7.4 earthquake from the Southwestern Pakistan recorded at the Acharya narender Dev College station in Delhi (epicentral distance $1293 \mathrm{~km}$ ) on 18 January 2011.

\section{Site Characterization}

The local site conditions play an important role in the recorded time history of earthquake ground motions. Different site conditions can induce amplifications of different period ranges in the response spectra $([19,20])$. Therefore, the local site conditions become important in ground motion analysis and in earthquake resistant designs. This network has recorded large numbers of ground motion histories. These data are invaluable for strongmotion studies and site effect analyses, as well as for the study of a practical site classification system. The objective of site classification is to classify a group of strong- 
motion station sites into several classes so that the conditions within the same site class are similar and design engineers may understand the general site condition by the class that it belongs to.

Because quantitative subsurface soil properties are not commonly available for every site, the use of surface geology becomes important in understanding the subsurface geologic conditions.

Most site effect studies of earthquake ground motion are based on the soil properties in the upper 30 meters. Some researchers had combined the use of surface geology and shear-wave velocity for site classification [21].

Site characterization is a must for strong ground motion studies. Ideally, detailed geotechnical investigation using bore hole of 20 to 30 meter depth should be carried out at each site. Such data base is available for large number of strong motion stations of Japan. However, such tests are costly and therefore other simple approaches for site characterization are being employed at several places.

Characterization of strong motion stations in India was done by modifying [21] classification which is as shown in Appendixes 1 and 2. Classification is based on physical descriptions of the near surface materials by modifying [21] as shown in Appendix 3. Hence, classification is mainly based on rock/soil types.

Information about the site geology have been gathered from maps viz., Seismotectonic Atlas of India and its Environs [22], Geological Maps of India [23] and books viz., Geology of Himachal Pradesh [24], Punjab, Haryana, Rajasthan [25], Uttarakhand [26], Bihar [27], Jharkhand [27], Assam [28], Arunachal Pradesh [29], Uttar Pradesh [26], and Geology and mineral resources of the states of Northeast India [30].

Information on rock types have been obtained based on color coding of the Seismotectonic Atlas of India representing particular rock type. For instance, the stations falling under pink color represent firm and hard quartzite and dolomite rocks and hence classed as A. The dark yellow represents sandstone, slates, limestone and dolomites and classed as B. Whereas, the strong motion stations falling in the region of light yellow color are represented by soil and classed as $C$ which falls under CF according to the Seismotectonic Atlas means alluvial deposits along foredeep (Figure 8).

\section{Earthquake Early Warning System}

The IIT network is planning to connect more stations, particularly strong-motion accelerograph stations, to the online network, so that a reliable earthquake early warning system (EEW) can be developed. The term EEW is used to describe real time earthquake information systems that have the potential to provide warning prior to significant ground shaking. This is possible by rapidly

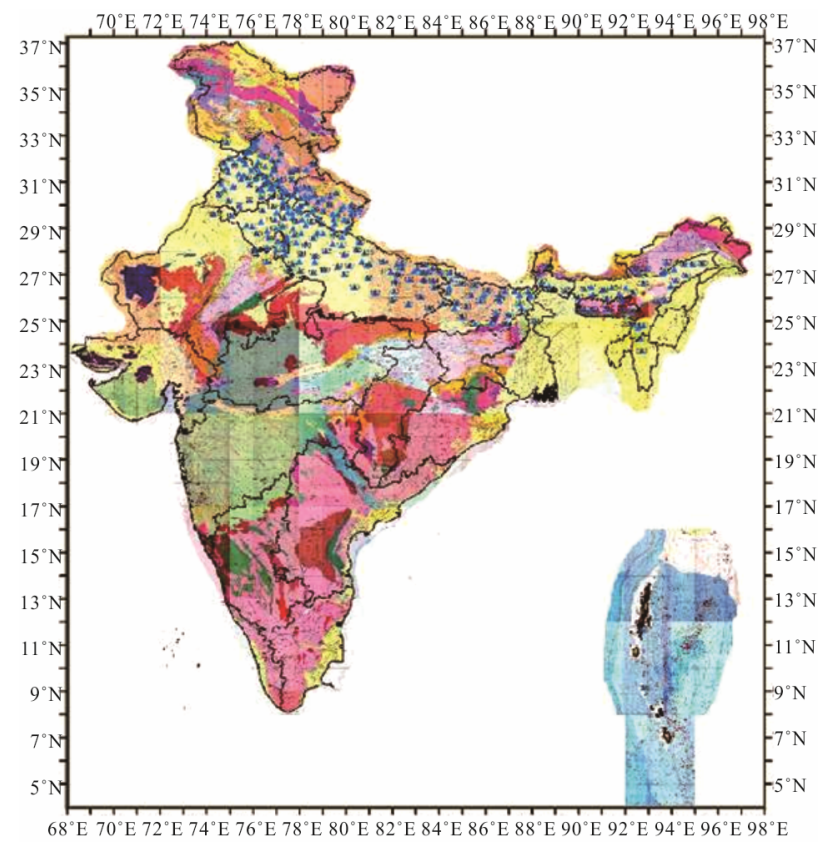

Figure 8. Location of strong ground motion accelerograph stations on different rock/soil type (after [31]).

detecting the ground motion radiating from an earthquake rupture and estimating the resulting ground shaking that will occur later in time either at the same location or some other location. Warning times range from a few seconds to a little more than a minute and are primarily a function of the distance of the user from the epicentre.

EEW systems are operational in several countries/areas like Japan, Taiwan, Mexico, Turkey, Romania and are under development in USA, Switzerland, China and Italy. In countries/areas like Japan, Taiwan and Mexico this system has several success stories although one or two false/missed alarms have also been reported. In most cases alarms could be issued within first ten second of first detection of arrival of earthquake. Relevance and possibility of getting full advantage of EEW system in northern India is perhaps the maximum, in comparison to any other place in world. This is due to the fact that, for northern India, potential source of large earthquakes are located in Himalayas whereas centres of large population as well as big industrial hubs (including our capital Delhi) are in plains adjoining Himalayas. Thick population density and poor adherence to earthquake resistant practices has substantially increased the seismic vulnerability of this region. However, in case of a large earthquake in Himalayas, most of these places can have a lead time of 30 to 70 seconds before the damaging seismic waves arrive. If this real-time seismological information is adequately tuned to the operational requirements of technical systems, life and industrial loss could be significantly reduced. Needless to say, for earthquake disaster mitigation, 
a successful EEW system can be the keystone.

For last about two years, few students of Department of Earthquake Engineering at IIT Roorkee have done research related to EEW for their M. Tech/Ph.D. dissertation. Research is also in advanced stage in searching other attributes for issue of alarms from initial few seconds of P-onset like predominant period, peak displacement, seismic intensity and root square velocity. Relationship of these attributes with magnitude for varying window length is being studied. These results are being interpreted for Indian data set and data sets of other countries and it is expected that three to four attributes for issue of alarm will be identified. Alarm will then be decided with some voting mechanism between these attributes. As the alert/alarm will get updated at regular interval of time during the shaking, some attributes for S-phase of motion will also be searched.

Presently, the network is limited to offline processing. The IIT network is planning to install EEW in Himalays for which funds are awaited. IIT is also planning to make some of the stations real time, so that nearly shake maps can be developed.

\section{Concluding Remarks}

From this network wealth of strong motion data is getting available which are being used at National and International level by engineers and scientists. A website having address www.pesmos.in is developed through which data is being disseminated to registered users of the website. It is now extremely important that this national asset is nurtured so that it may flourish to serve the nation to its maximum capability. Since strong ground motion data from this network is now getting routinely available, it is essential to make use of this data and fill the gap in the research areas earlier caused due to paucity of data. Although the data base generated from this instrumentation is currently quite small (about 500 time histories from 180 earthquakes), but is good enough to stir substantial research activity. This project aims to use our strong ground motion data for reshaping and upgrading various prevalent relationships for earthquake ground motion parameters, which have been made using strong ground motion data sets from other parts of the world.

\section{Acknowledgements}

The authors wish to thank the Department of Science and Technology (DST), government of India, and the Ministry of Earth Sciences (MoES) for providing funds to execute this project. Successful implementation of a project of this size requires support from several individuals and agencies, which we thankfully acknowledge. We received tremendous support from the National Infor- matics Centre, New Delhi, during the course of the project. Support from the district administration of each instrument location was also very important for us. We received good support from the staff of SWAN of various states, for which we are thankful. We are thankful to the faculty of the Department of Earthquake Engineering and to the Dean of Sponsored Research and Industrial Consultancy, Indian Institute of Technology, Roorkee, for their constant support and encouragement. We are also thankful to the technical and administrative staff of the Department of Earthquake Engineering, who have made important contributions in this project.

\section{REFERENCES}

[1] BIS, "Criteria for Earthquake Resistant Design of Structures, Part I-General Provisions Andbuildings,” Bureau of Indian Standards, 2002.

[2] S. Chopra, R. B. S. Yadav, H. Patel, S. Kumar, K. M. Rao, B. K. Rastogi, A. Hameed and S. Srivastava, "The Gujarat (India) Seismic Network,” Seismological Research Letters, Vol. 79, No. 6, 2008, pp. 806-815. doi:10.1785/gssrl.79.6.806

[3] R. Bilham, F. Blume, R. Bendick and V. K. Gaur, "The Geodetic Constraints on the Translation and Deformation of India: Implications for Future Great Himalayan Earthquakes,” Current Science, Vol. 74, No. 3, 1998, pp. 213229.

[4] A. Gansser, "Geology of the Himalayas," Interscience, New York, 1964.

[5] P. Molnar and W. P. Chen, "Seismicity and Mountain Building”, In: K. Hsu, Ed., Mountain Building Processes, Academic Press, New York, 1982, pp. 41-57.

[6] L. Seeber and J. G. Armbruster, "Great Detachment Earthquakes along the Himalayan Arc and Long-Term Forecasting,” In: M. Ewing, Ed., Earthquake Prediction: An International Review, American Geophysical Union, Washington DC, 1981, pp. 259-277.

[7] K. N. Khattri, "An Evaluation of Earthquake Hazard and Risk in Northern India,” Himalayan Geology, Vol. 20, No. 1, 1999, pp. 1-46.

[8] R. Bilham and V. K. Gaur, "The Geodetic Contribution to Indian Seismotectonics,” Current Science, Vol. 79, No. 9, 2000, pp. 259-269.

[9] S. K. Singh, W. K. Mohanty, B. K. Bansal and G. S. Roonwal, "Ground Motion in Delhi from Future Large/ Great Earthquakes in the Central Seismic Gap of the Himalayan Arc," Bulletin of the Seismological Society of America, Vol. 92, No. 2, 2002, pp. 555-569. doi:10.1785/0120010139

[10] K. N. Khattri, “An Evaluation of Earthquake Hazard and Risk in Northern India,” Himalayan Geology, Vol. 20, No. 1, 1999, pp. 1-46.

[11] R. Bilham, "Location and Magnitude of the Nepal Earthquake and Its Relation to the Rupture Zones of the Contiguous Great Himalayan Earthquakes,” Current Science, Vol. 69, No. 2, 1995, pp. 101-128. 
[12] H. Lyo-Caen and P. Molnar, "Gravity Anomalies, Flexure of the Indian Plate, and Structure, Support, and Evolution of the Himalaya and Ganga Basin,” Tectonics, Vol. 4, No. 6, 1985, pp. 513-538. doi:10.1029/TC004i006p00513

[13] J. Avouac and P. Tapponnier, "Kinematic Model of Active Deformation in Central Asia," Geophysical Research Letters, Vol. 20, No. 10, 1993, pp. 895-898. doi:10.1029/93GL00128

[14] V. K. Gahalaut and R. Chander, "On Interseismic Elevation Changes and Strain Accumulation for Great Thrust Earthquakes in the Nepal Himalaya,” Geophysical Research Letters, Vol. 24, No. 9, 1997, pp. 1011-1014.

[15] J. R. Kayal, S. S. Arefiev, S. Barua, D. Hazarika, N. Gogoi, A. Kumar, S. N. Chowdhury and S. Kalita, "Shillong Plateau Earthquakes in Northeast India Region: Complex Tectonic Model," Current Science, Vol. 19, No. 1, 2006, pp. 109-114.

[16] A. R. Chandrasekaran and J. D. Das, "Strong Motion Arrays in India and Analysis of Data from Shillong Array,” Current Scence, Vol. 62, No. 1-2, 1992, pp. 233250.

[17] H. Mittal, S. Gupta, A. Srivastava, R. N. Dubey and A. Kumar, "National Strong Motion Instrumentation Project: An Overview," 13th Symposium on Earthquake Engineering, Indian Institute of Technology, Roorkee, 18-20 December 2006, pp. 107-115.

[18] A. Kumar, H. Mittal, R. Sachdeva and A. Kumar, "Indian Strong Motion Instrumentation Network,” Seismological Research Letters, Vol. 83, No. 1, 2012, pp. 59-66. doi:10.1785/gssrl.83.1.59

[19] H. B. Seed, C. Ugas and J. Lysmer, "Site-Dependent Spectra for Earthquake-Resistant Design," Bulletin of the Seismological Society of America, Vol. 66, No. 1, 1976, pp. 221-243.
[20] B. Mohraz, “A Study of Earthquake Response Spectra for Different Geological Conditions," Bulletin of the Seismological Society of America, Vol. 66, No. 3, 1976, pp. 915-935.

[21] R. D. Borcherdt, "Estimates of Site-Dependent Response Spectra for Design (Methodology and Justification)," Earthquake Spectra, Vol. 10, No. 4, 1976, pp. 617-653. doi:10.1193/1.1585791

[22] GSI, "Seismotectonic Atlas of India and Its Environs," Geological Survey of India, Bangalore, 2000.

[23] GSI, “Geological Map of India,” 7th Edition, Geological Survey of India, Bangalore, 1998.

[24] O. N. Bhargava and S. V. Srikantia, "Geology of Himachal Pradesh,” Geological Survey of India, Bangalore, 1998.

[25] G. Malhotra, S. Sinha and M. Mohanty, "Geology of Rajasthan,” Geological Survey of India, Bangalore, 1998.

[26] G. Kumar, "Geology of Uttar Pradesh and Uttaranchal," Geological Survey of India, Bangalore, 2005.

[27] T. M. Mahavedan, "Geology of Bihar and Jharkhand," Geological Survey of India, Bangalore, 2002.

[28] A. B. G. Das and A. K. Biswas, "Geology of Assam," Geological Survey of India, Bangalore, 2000.

[29] G. Kumar, “Geology of Arunachal Pradesh,” Geological Survey of India, Bangalore, 1997.

[30] GSI, “Geology and Mineral Resources of the States of India, Part-IV (Arunachal Pradesh, Assam, Manipur, Meghalaya, Mizoram, Nagaland and Tripura),” GSI Miscellaneous Publications, 1974.

[31] R. Ramhmachhuani, "Site Characterization of Strong Motion Accelerograph Stations,” Master's Teaching Thesis, Indian Institute of Technology, Roorkee, 2011. 


\section{Appendix 1}

List of strong motion accelerographs (SMA) stations, their locations and site geology.

\begin{tabular}{|c|c|c|c|c|c|}
\hline Station no. & Station name & Latitude & Longitude & Site class & Site geology according to seismotectonic atlas \\
\hline 1 & Almora & 29.60 & 79.66 & A & Schist, granodiorites, gneiss \\
\hline 2 & Bageshwar & 29.83 & 79.77 & A & Quartzite, dolomites \\
\hline 3 & Chamoli & 30.41 & 79.32 & A & Quartzite, dolomites \\
\hline 4 & Champawat & 29.33 & 80.09 & A & granite \\
\hline 5 & Dehradun & 30.32 & 78.04 & $\mathrm{C}$ & Soil (slope washed) \\
\hline 6 & Haridwar & 29.97 & 78.07 & $\mathrm{C}$ & alluvium \\
\hline 7 & Nainital & 29.38 & 79.46 & B & Sandstones/slates/limestones/dolomites \\
\hline 8 & Pauri & 30.15 & 78.78 & A & phyllites \\
\hline 9 & Pithoragarh & 29.58 & 80.21 & A & Phyllites/slates/limestones blue with dots \\
\hline 10 & Rudraprayag & 30.29 & 78.98 & A & Quartzite/slates \\
\hline 11 & Tehri & 30.37 & 78.43 & A & Phyllites \\
\hline 12 & Udham Singh Nagar & 29.00 & 79.40 & $\mathrm{C}$ & Soil (slope washed) \\
\hline 13 & Uttarkashi & 30.73 & 78.44 & A & Quartzite/slates \\
\hline 14 & Barkot & 30.81 & 78.21 & A & Granite/phyllite/slates \\
\hline 15 & Chakrata & 30.69 & 77.90 & B & slitstones/slates \\
\hline 16 & Dhanaulti & 30.43 & 78.24 & B & Slates/siltstones/limestones/sandstones \\
\hline 17 & Dharchula & 29.85 & 80.55 & A & Phyllites/slates/limestones \\
\hline 18 & Dhumakot & 29.75 & 79.02 & A & Phyllites \\
\hline 19 & Garsain & 30.05 & 79.29 & A & Schist, granodiorites, gneiss \\
\hline 20 & Ghansali & 30.43 & 78.66 & A & Quartzite/slates \\
\hline 21 & Haldwani & 29.22 & 79.53 & $\mathrm{C}$ & Soil (slope washed) \\
\hline 22 & Joshimath & 30.57 & 79.58 & A & Granite/gneiss/quartzite \\
\hline 23 & Kapkot & 29.94 & 79.90 & A & Dolomite/limestones \\
\hline 24 & Kashipur & 29.21 & 78.96 & $\mathrm{C}$ & Soils (slope washed) \\
\hline 25 & Khatima & 28.92 & 79.97 & $\mathrm{C}$ & Soils (slope washed) \\
\hline 26 & Kotdwar & 29.75 & 78.52 & B & Sandstones/shales \\
\hline 27 & Laksar & 29.74 & 78.03 & $\mathrm{C}$ & Alluvium \\
\hline 28 & Lansdown & 29.84 & 78.68 & A & Schist, granodiorites, gneiss \\
\hline 29 & Munsyari & 30.07 & 80.24 & A & Schist, granodiorites, gneiss \\
\hline 30 & Patti & 29.41 & 79.93 & A & Schist, granodiorites, gneiss \\
\hline 31 & Ranikhet & 29.64 & 79.43 & A & Schist, granodiorites, gneiss \\
\hline 32 & Rishikesh & 30.12 & 78.28 & $\mathrm{C}$ & Soils (slope washed) \\
\hline 33 & Tanakpur & 29.07 & 80.11 & $\mathrm{C}$ & Alluvium \\
\hline 34 & Didihat & 29.77 & 80.30 & A & Schist, granodiorites, gneiss \\
\hline 35 & Vikasnagar & 30.45 & 77.75 & $\mathrm{C}$ & Soils (slope washed) \\
\hline
\end{tabular}




\section{Continued}

\begin{tabular}{|c|c|c|c|c|c|}
\hline 36 & Bilaspur & 31.34 & 76.76 & $\mathrm{~B}$ & Sandstones/shales \\
\hline 37 & Chamba & 32.55 & 76.13 & A & Granitoids \\
\hline 38 & Dharamshala & 32.21 & 76.32 & $\mathrm{~B}$ & Sandstones/shales \\
\hline 39 & Hamirpur & 31.69 & 76.52 & $\mathrm{~B}$ & Sandstones/shales \\
\hline 40 & Keylong & 32.56 & 77.01 & A & Phyllite, quartzite, schist \\
\hline 41 & Kullu & 31.96 & 77.11 & A & Phyllite, quartzite, schist, gneiss \\
\hline 42 & Mandi & 31.71 & 76.93 & B & Sandstones/shales \\
\hline 43 & Nahan & 30.56 & 77.30 & $\mathrm{~B}$ & Sandstones/shales \\
\hline 44 & RekongPeo & 31.54 & 78.27 & A & Granitoids and basic volcanics, gneiss and magmatites \\
\hline 45 & Shimla & 31.11 & 77.17 & A & Quartzite, gneiss, schist \\
\hline 46 & Solan & 30.91 & 77.10 & A & Limestones, dolomite, sandstones \\
\hline 47 & Una & 31.47 & 76.26 & $\mathrm{C}$ & Soils (slope washed) \\
\hline 48 & Amb & 31.69 & 76.12 & $\mathrm{C}$ & Soils (slope washed) \\
\hline 49 & Dadahu & 30.60 & 77.43 & $\mathrm{~B}$ & Sandstones/shales \\
\hline 50 & Dalhousie & 32.52 & 75.96 & A & Quartzite, gneiss, schist, phyllite \\
\hline 51 & Dehra & 31.88 & 76.22 & $\mathrm{~B}$ & Sandstones/shales \\
\hline 52 & Jubbal & 31.11 & 77.66 & A & Granitoids and basic volcanics, gneiss and magmatites \\
\hline 53 & Kasauli & 30.90 & 76.96 & $\mathrm{~B}$ & Sandstones/shales \\
\hline 54 & Manali & 32.25 & 77.19 & A & Phyllite, quartzite, schist, gneiss \\
\hline 55 & Nalagarh & 31.04 & 76.72 & B & Sandstones/shales \\
\hline 56 & Nathhpa & 31.55 & 77.92 & A & Gneissic complex \\
\hline 57 & Jogindernager & 31.99 & 76.80 & B & Sandstones/shales \\
\hline 58 & Nurpur & 32.30 & 75.88 & B & Sandstones/shales \\
\hline 59 & Pachchhad & 30.72 & 77.19 & B & Sandstones/shales \\
\hline 60 & Palampur & 32.11 & 76.54 & B & Sandstones/shales \\
\hline 61 & Paonta Sahib & 30.44 & 77.62 & $\mathrm{~B}$ & Sandstones \\
\hline 62 & Puh & 31.76 & 78.58 & A & Phyllite, quartzite, schist \\
\hline 63 & Rampur & 31.45 & 77.63 & A & Granitoids and basic volcanics, phyllite \\
\hline 64 & Saluni & 32.70 & 76.06 & A & Granitoids \\
\hline 65 & Sundernagar & 31.52 & 76.88 & A & Sandstones, shales, dolomite \\
\hline 66 & Tisa & 32.84 & 76.15 & A & Phyllite, quartzite, schist \\
\hline 67 & Amritsar & 31.64 & 74.86 & $\mathrm{C}$ & Alluvium \\
\hline 68 & Bhatinda & 30.20 & 74.95 & $\mathrm{C}$ & Alluvium \\
\hline 69 & Faridkot & 30.68 & 74.76 & $\mathrm{C}$ & Alluvium \\
\hline 70 & Fathehgarh Saheb & 30.65 & 76.39 & $\mathrm{C}$ & Alluvium \\
\hline 71 & Firozpur & 30.93 & 74.61 & $\mathrm{C}$ & Alluvium \\
\hline 72 & Gurdaspur & 32.04 & 75.41 & $\mathrm{C}$ & Alluvium \\
\hline
\end{tabular}


Continued

\begin{tabular}{|c|c|c|c|c|c|}
\hline 73 & Hoshiarpur & 31.52 & 75.93 & $\mathrm{C}$ & Alluvium \\
\hline 74 & Jallandhar & 31.32 & 75.59 & $\mathrm{C}$ & Alluvium \\
\hline 75 & Kapurthala & 31.38 & 75.38 & $\mathrm{C}$ & Alluvium \\
\hline 76 & Ludhiana & 30.90 & 75.84 & $\mathrm{C}$ & Alluvium \\
\hline 77 & Mansa & 30.00 & 75.41 & $\mathrm{C}$ & Alluvium \\
\hline 78 & Moga & 30.83 & 75.15 & $\mathrm{C}$ & Alluvium \\
\hline 79 & Muktsar & 30.47 & 74.54 & $\mathrm{C}$ & Alluvium \\
\hline 80 & Nawanshahar & 31.12 & 76.12 & $\mathrm{C}$ & Alluvium \\
\hline 81 & Patiala & 30.35 & 76.38 & $\mathrm{C}$ & Alluvium \\
\hline 82 & Rupnagar & 30.98 & 76.52 & $\mathrm{C}$ & Alluvium \\
\hline 83 & Sangrur & 30.25 & 75.84 & $\mathrm{C}$ & Alluvium \\
\hline 84 & Mohali & 30.73 & 76.72 & $\mathrm{C}$ & Alluvium \\
\hline 85 & Taran Taran & 31.45 & 74.93 & $\mathrm{C}$ & Alluvium \\
\hline 86 & Ajnala & 31.84 & 74.76 & $\mathrm{C}$ & Alluvium \\
\hline 87 & Anandpur Saheb & 31.24 & 76.49 & $\mathrm{C}$ & Alluvium \\
\hline 88 & Batala & 31.82 & 75.20 & $\mathrm{C}$ & Alluvium \\
\hline 89 & Chamkaur saheb & 30.89 & 76.42 & $\mathrm{C}$ & Alluvium \\
\hline 90 & Dasua & 31.81 & 75.66 & $\mathrm{C}$ & Alluvium \\
\hline 91 & Dera Baba Nanak & 32.04 & 75.02 & $\mathrm{C}$ & Alluvium \\
\hline 92 & Dhar Kalan & 32.41 & 75.80 & $\mathrm{C}$ & Alluvium \\
\hline 93 & GarhShankar & 31.23 & 76.13 & $\mathrm{C}$ & Alluvium \\
\hline 94 & Khanna & 30.70 & 76.24 & $\mathrm{C}$ & Alluvium \\
\hline 95 & Mukerian & 31.95 & 75.61 & $\mathrm{C}$ & Alluvium \\
\hline 96 & Nakodar & 31.12 & 75.49 & $\mathrm{C}$ & Alluvium \\
\hline 97 & Pathankot & 32.27 & 75.66 & $\mathrm{C}$ & Alluvium \\
\hline 98 & Phagwara & 31.21 & 75.77 & $\mathrm{C}$ & Alluvium \\
\hline 99 & Ambala & 30.37 & 76.77 & $\mathrm{C}$ & Alluvium \\
\hline 100 & Bhiwani & 28.81 & 76.14 & $\mathrm{C}$ & Alluvium \\
\hline 101 & Fatehabad & 30.65 & 76.39 & $\mathrm{C}$ & Alluvium \\
\hline 102 & Faridabad & 28.38 & 77.32 & $\mathrm{C}$ & Alluvium \\
\hline 103 & Gurgaon & 28.45 & 77.03 & $\mathrm{C}$ & Alluvium \\
\hline 104 & Hisar & 29.13 & 75.71 & $\mathrm{C}$ & Alluvium \\
\hline 105 & Jhajjar & 28.60 & 76.66 & $\mathrm{C}$ & Alluvium \\
\hline 106 & Jind & 29.31 & 76.34 & $\mathrm{C}$ & Alluvium \\
\hline 107 & Kaithal & 29.80 & 76.42 & $\mathrm{C}$ & Alluvium \\
\hline 108 & Karnal & 29.69 & 77.00 & $\mathrm{C}$ & Alluvium \\
\hline 109 & Kurukshetra & 29.97 & 76.87 & $\mathrm{C}$ & Alluvium \\
\hline
\end{tabular}




\section{Continued}

\begin{tabular}{|c|c|c|c|c|c|}
\hline 110 & Mewat & 28.09 & 77.00 & $\mathrm{C}$ & Alluvium \\
\hline 111 & Narnaul & 28.06 & 76.11 & $\mathrm{C}$ & Alluvium \\
\hline 112 & Panipat & 29.40 & 76.95 & $\mathrm{C}$ & Alluvium \\
\hline 113 & Panchkula & 30.70 & 76.87 & $\mathrm{C}$ & Alluvium \\
\hline 114 & Rewari & 28.18 & 76.61 & $\mathrm{C}$ & Alluvium \\
\hline 115 & Rohtak & 28.90 & 76.59 & $\mathrm{C}$ & Alluvium \\
\hline 116 & Sirsa & 29.55 & 75.05 & $\mathrm{C}$ & Alluvium \\
\hline 117 & Sonipat & 29.00 & 77.00 & $\mathrm{C}$ & Alluvium \\
\hline 118 & Yamunanagar & 30.15 & 77.29 & $\mathrm{C}$ & Alluvium \\
\hline 119 & Ballabhgarh & 28.34 & 77.32 & $\mathrm{C}$ & Alluvium \\
\hline 120 & Hansi & 29.09 & 75.96 & $\mathrm{C}$ & Alluvium \\
\hline 121 & Hodal & 27.89 & 77.38 & $\mathrm{C}$ & Alluvium \\
\hline 122 & Palwal & 28.13 & 77.33 & $\mathrm{C}$ & Alluvium \\
\hline 123 & Sadhura & 30.38 & 77.22 & $\mathrm{C}$ & Alluvium \\
\hline 124 & Alwar & 27.57 & 76.59 & A & Gneiss/schist \\
\hline 125 & Bharatpur & 27.21 & 77.51 & $\mathrm{C}$ & Aeolian \\
\hline 126 & Hanumangarh & 29.63 & 74.29 & $\mathrm{C}$ & Aeolian \\
\hline 127 & Jammu & 32.73 & 74.87 & B & Sandstones/shales \\
\hline 128 & Car Nicobar & 9.18 & 92.82 & B & Sandstones/shales \\
\hline 129 & Port Blair & 11.66 & 92.74 & B & Sandstones/shales \\
\hline 130 & Agra & 27.18 & 78.01 & $\mathrm{C}$ & Alluvium \\
\hline 131 & Aligarh & 27.91 & 78.07 & $\mathrm{C}$ & Alluvium \\
\hline 132 & Azamgarh & 26.06 & 83.19 & $\mathrm{C}$ & Alluvium \\
\hline 133 & Badaun & 28.02 & 79.13 & $\mathrm{C}$ & Alluvium \\
\hline 134 & Bahraich & 27.57 & 81.59 & $\mathrm{C}$ & Alluvium \\
\hline 135 & Balia & 25.77 & 84.14 & $\mathrm{C}$ & Alluvium \\
\hline 136 & Balrampur & 27.44 & 82.17 & $\mathrm{C}$ & Alluvium \\
\hline 137 & Bareilly & 28.34 & 79.42 & $\mathrm{C}$ & Alluvium \\
\hline 138 & Basti & 26.79 & 82.72 & $\mathrm{C}$ & Alluvium \\
\hline 139 & Bijnor & 29.38 & 78.13 & $\mathrm{C}$ & Alluvium \\
\hline 140 & BulandShahar & 28.40 & 77.85 & $\mathrm{C}$ & Alluvium \\
\hline 141 & Devria & 26.50 & 83.78 & $\mathrm{C}$ & Alluvium \\
\hline 142 & Eta & 27.56 & 78.65 & $\mathrm{C}$ & Alluvium \\
\hline 143 & Faizabad & 26.77 & 82.13 & $\mathrm{C}$ & Alluvium \\
\hline 144 & Farrukhabad & 27.36 & 79.64 & $\mathrm{C}$ & Alluvium \\
\hline 145 & Gaziabad & 28.67 & 77.45 & $\mathrm{C}$ & Alluvium \\
\hline 146 & Gazipur & 25.57 & 83.57 & $\mathrm{C}$ & Alluvium \\
\hline
\end{tabular}


Continued

\begin{tabular}{|c|c|c|c|c|c|}
\hline 147 & Gonda & 27.13 & 81.94 & $\mathrm{C}$ & Alluvium \\
\hline 148 & Gorakhpur & 26.75 & 83.37 & $\mathrm{C}$ & Alluvium \\
\hline 149 & Hardoi & 27.40 & 80.13 & $\mathrm{C}$ & Alluvium \\
\hline 150 & Hathras & 27.58 & 77.98 & $\mathrm{C}$ & Alluvium \\
\hline 151 & Jaunpur & 25.73 & 82.69 & $\mathrm{C}$ & Alluvium \\
\hline 152 & Kannauj & 27.03 & 79.92 & $\mathrm{C}$ & Alluvium \\
\hline 153 & Kanpur & 26.48 & 80.35 & $\mathrm{C}$ & Alluvium \\
\hline 154 & KushuNagar & 26.75 & 83.76 & $\mathrm{C}$ & Alluvium \\
\hline 155 & Lakhimpur & 27.95 & 80.79 & $\mathrm{C}$ & Alluvium \\
\hline 156 & Lucknow & 26.85 & 80.93 & $\mathrm{C}$ & Alluvium \\
\hline 157 & Maharaj Ganj & 27.14 & 83.54 & $\mathrm{C}$ & Alluvium \\
\hline 158 & Mainpuri & 27.24 & 79.05 & $\mathrm{C}$ & Alluvium \\
\hline 159 & Mathura & 27.47 & 77.69 & $\mathrm{C}$ & Alluvium \\
\hline 160 & Meerut & 28.99 & 77.72 & $\mathrm{C}$ & Alluvium \\
\hline 161 & Moradabad & 28.85 & 78.77 & $\mathrm{C}$ & Alluvium \\
\hline 162 & MuzaffarNagar & 29.47 & 77.70 & $\mathrm{C}$ & Alluvium \\
\hline 163 & Noida & 28.51 & 77.48 & $\mathrm{C}$ & Alluvium \\
\hline 164 & Pratap Garh & 25.92 & 81.99 & $\mathrm{C}$ & Alluvium \\
\hline 165 & Pilibhit & 28.65 & 79.82 & $\mathrm{C}$ & Alluvium \\
\hline 166 & Rai Bareilly & 26.21 & 81.25 & $\mathrm{C}$ & Alluvium \\
\hline 167 & Rampur & 28.79 & 79.01 & $\mathrm{C}$ & Alluvium \\
\hline 168 & Saharanpur & 29.95 & 77.55 & $\mathrm{C}$ & Alluvium \\
\hline 169 & Shahjahanpur & 27.89 & 79.92 & $\mathrm{C}$ & Alluvium \\
\hline 170 & Sidharth Nagar & 27.28 & 83.07 & $\mathrm{C}$ & Alluvium \\
\hline 171 & Sitapur & 27.57 & 80.68 & $\mathrm{C}$ & Alluvium \\
\hline 172 & SultanPur & 26.26 & 82.07 & $\mathrm{C}$ & Alluvium \\
\hline 173 & Anoop Sahar & 28.35 & 78.27 & $\mathrm{C}$ & Alluvium \\
\hline 174 & Baheri & 28.78 & 79.50 & $\mathrm{C}$ & Alluvium \\
\hline 175 & Bansi & 27.17 & 82.93 & $\mathrm{C}$ & Alluvium \\
\hline 176 & Baraut & 29.10 & 77.26 & $\mathrm{C}$ & Alluvium \\
\hline 177 & Bisalpur & 28.29 & 79.80 & $\mathrm{C}$ & Alluvium \\
\hline 178 & Biswan & 27.49 & 81.00 & $\mathrm{C}$ & Alluvium \\
\hline 179 & Chandausi & 29.46 & 78.79 & $\mathrm{C}$ & Alluvium \\
\hline 180 & Chandpur & 29.15 & 78.26 & $\mathrm{C}$ & Alluvium \\
\hline 181 & Chhata(kosi) & 29.72 & 77.50 & $\mathrm{C}$ & Alluvium \\
\hline 182 & Deoband & 29.68 & 77.68 & $\mathrm{C}$ & Alluvium \\
\hline 183 & Dhampur & 29.31 & 78.50 & $\mathrm{C}$ & Alluvium \\
\hline
\end{tabular}




\section{Continued}

\begin{tabular}{|c|c|c|c|c|c|}
\hline 184 & Garh Mukteshwar & 28.79 & 78.09 & $\mathrm{C}$ & Alluvium \\
\hline 185 & Gola Gokarnath & 28.09 & 80.46 & $\mathrm{C}$ & Alluvium \\
\hline 186 & Hapur & 28.73 & 77.78 & $\mathrm{C}$ & Alluvium \\
\hline 187 & Jansath (Khatauli) & 29.33 & 77.86 & $\mathrm{C}$ & Alluvium \\
\hline 188 & Kashganj & 27.81 & 78.64 & $\mathrm{C}$ & Alluvium \\
\hline 189 & Laharpur (Tambaur) & 27.41 & 80.89 & $\mathrm{C}$ & Alluvium \\
\hline 190 & Mankapur & 27.06 & 82.21 & $\mathrm{C}$ & Alluvium \\
\hline 191 & Nakur (Gangoh) & 29.92 & 77.30 & $\mathrm{C}$ & Alluvium \\
\hline 192 & Nautanwa & 27.44 & 83.42 & $\mathrm{C}$ & Alluvium \\
\hline 193 & Nazibabad & 29.61 & 78.35 & $\mathrm{C}$ & Alluvium \\
\hline 194 & Nichlaul (Siswa) & 27.31 & 83.72 & $\mathrm{C}$ & Alluvium \\
\hline 195 & Palia & 28.43 & 80.58 & $\mathrm{C}$ & Alluvium \\
\hline 196 & Pharenda & 27.11 & 83.27 & $\mathrm{C}$ & Alluvium \\
\hline 197 & Sambhal & 28.59 & 78.58 & $\mathrm{C}$ & Alluvium \\
\hline 198 & Shamli & 29.46 & 77.34 & $\mathrm{C}$ & Alluvium \\
\hline 199 & Shikohabad & 27.11 & 78.58 & $\mathrm{C}$ & Alluvium \\
\hline 200 & Tulsipur (Jarwa) & 27.53 & 82.40 & $\mathrm{C}$ & Alluvium \\
\hline 201 & Utraula & 27.31 & 82.41 & $\mathrm{C}$ & Alluvium \\
\hline 202 & Ara & 25.56 & 84.66 & $\mathrm{C}$ & Alluvium \\
\hline 203 & Araria & 26.13 & 87.47 & $\mathrm{C}$ & Alluvium \\
\hline 204 & Banka & 24.89 & 86.91 & $\mathrm{C}$ & Alluvium \\
\hline 205 & Bettiah & 26.80 & 84.52 & $\mathrm{C}$ & Alluvium \\
\hline 206 & Bhagalpur & 25.26 & 86.99 & $\mathrm{C}$ & Alluvium \\
\hline 207 & Bihar Shariff & 25.20 & 85.52 & $\mathrm{C}$ & Alluvium \\
\hline 208 & Chapra & 25.78 & 84.74 & $\mathrm{C}$ & Alluvium \\
\hline 209 & Darbhanga & 26.12 & 85.90 & $\mathrm{C}$ & Alluvium \\
\hline 210 & Gopalganj & 26.47 & 84.44 & $\mathrm{C}$ & Alluvium \\
\hline 211 & Jamui & 24.93 & 86.23 & $\mathrm{C}$ & Alluvium \\
\hline 212 & jehanabad & 25.20 & 84.99 & $\mathrm{C}$ & Alluvium \\
\hline 213 & Katihar & 25.56 & 87.55 & $\mathrm{C}$ & Alluvium \\
\hline 214 & kishanganj & 26.10 & 87.95 & $\mathrm{C}$ & Alluvium \\
\hline 215 & Madhubani & 26.35 & 86.07 & $\mathrm{C}$ & Alluvium \\
\hline 216 & Motihari & 26.63 & 84.90 & $\mathrm{C}$ & Alluvium \\
\hline 217 & Munger & 25.38 & 86.46 & $\mathrm{C}$ & Alluvium \\
\hline 218 & Muzzafarpur & 26.12 & 85.38 & $\mathrm{C}$ & Alluvium \\
\hline 219 & Navada & 24.89 & 85.54 & $\mathrm{C}$ & Alluvium \\
\hline 220 & Patna & 25.62 & 85.15 & $\mathrm{C}$ & Alluvium \\
\hline
\end{tabular}


Continued

\begin{tabular}{|c|c|c|c|c|c|}
\hline 221 & Purnia & 25.77 & 87.47 & $\mathrm{C}$ & Alluvium \\
\hline 222 & Saharsa & 25.89 & 86.59 & $\mathrm{C}$ & Alluvium \\
\hline 223 & Samastipur & 25.86 & 85.78 & $\mathrm{C}$ & Alluvium \\
\hline 224 & Saupaul & 26.13 & 86.61 & $\mathrm{C}$ & Alluvium \\
\hline 225 & Sitamari & 26.56 & 85.52 & $\mathrm{C}$ & Alluvium \\
\hline 226 & Siwan & 26.23 & 84.36 & $\mathrm{C}$ & Alluvium \\
\hline 227 & Bagha & 27.13 & 84.06 & $\mathrm{C}$ & Alluvium \\
\hline 228 & Bahadurganj & 26.26 & 87.83 & $\mathrm{C}$ & Alluvium \\
\hline 229 & Forbesganj & 26.30 & 87.25 & $\mathrm{C}$ & Alluvium \\
\hline 230 & NarkatraGanj & 27.10 & 84.46 & $\mathrm{C}$ & Alluvium \\
\hline 231 & Raghopur & 26.30 & 86.84 & $\mathrm{C}$ & Alluvium \\
\hline 232 & Raxaul & 26.98 & 84.84 & $\mathrm{C}$ & Alluvium \\
\hline 233 & Darjeeling & 27.05 & 88.26 & A & Gneiss/schist \\
\hline 234 & Jalpaiguri & 26.52 & 88.73 & $\mathrm{C}$ & Alluvium \\
\hline 235 & Kooch Vihar & 26.32 & 89.44 & $\mathrm{C}$ & Alluvium \\
\hline 236 & Malda & 25.00 & 88.15 & $\mathrm{C}$ & Alluvium \\
\hline 237 & Siliguri & 26.71 & 88.43 & $\mathrm{C}$ & Soils (slope washed) \\
\hline 238 & Gangtok & 27.35 & 88.63 & A & Gneiss/schist \\
\hline 239 & Barpeta & 26.33 & 91.01 & $\mathrm{C}$ & Alluvium \\
\hline 240 & Bongaigaon & 26.47 & 90.56 & $\mathrm{C}$ & Soils (slope washed) \\
\hline 241 & Dhemaji & 27.47 & 94.56 & $\mathrm{C}$ & Alluvium \\
\hline 242 & Dhubri & 26.02 & 90.00 & $\mathrm{C}$ & Alluvium \\
\hline 243 & Dibrugarh & 27.47 & 94.91 & $\mathrm{C}$ & Alluvium \\
\hline 244 & Diphu & 25.84 & 93.44 & $\mathrm{~B}$ & Shale/sandstones \\
\hline 245 & Goalpara & 26.16 & 90.63 & $\mathrm{C}$ & Alluvium \\
\hline 246 & Golaghat & 26.51 & 93.97 & $\mathrm{~B}$ & Sandstones \\
\hline 247 & Guwhati & 26.19 & 91.75 & $\mathrm{C}$ & Alluvium \\
\hline 248 & Hailakandi & 24.68 & 92.56 & $\mathrm{C}$ & Alluvium \\
\hline 249 & Jorhat & 26.76 & 94.21 & $\mathrm{C}$ & Alluvium \\
\hline 250 & Karimganj & 24.87 & 92.35 & $\mathrm{C}$ & Alluvium \\
\hline 251 & Khokrajhar & 26.40 & 90.26 & $\mathrm{C}$ & Soils (slope washed) \\
\hline 252 & Mangaldai & 26.44 & 92.03 & $\mathrm{C}$ & Alluvium \\
\hline 253 & Morigaon & 26.25 & 92.34 & $\mathrm{C}$ & Alluvium \\
\hline 254 & Nalbari & 26.45 & 91.43 & $\mathrm{C}$ & Alluvium \\
\hline 255 & Naogaon & 26.35 & 92.69 & $\mathrm{C}$ & Alluvium \\
\hline 256 & North Lakhimpur & 27.24 & 94.11 & $\mathrm{C}$ & Alluvium \\
\hline 257 & Sibsagar & 26.99 & 94.63 & $\mathrm{C}$ & Alluvium \\
\hline
\end{tabular}




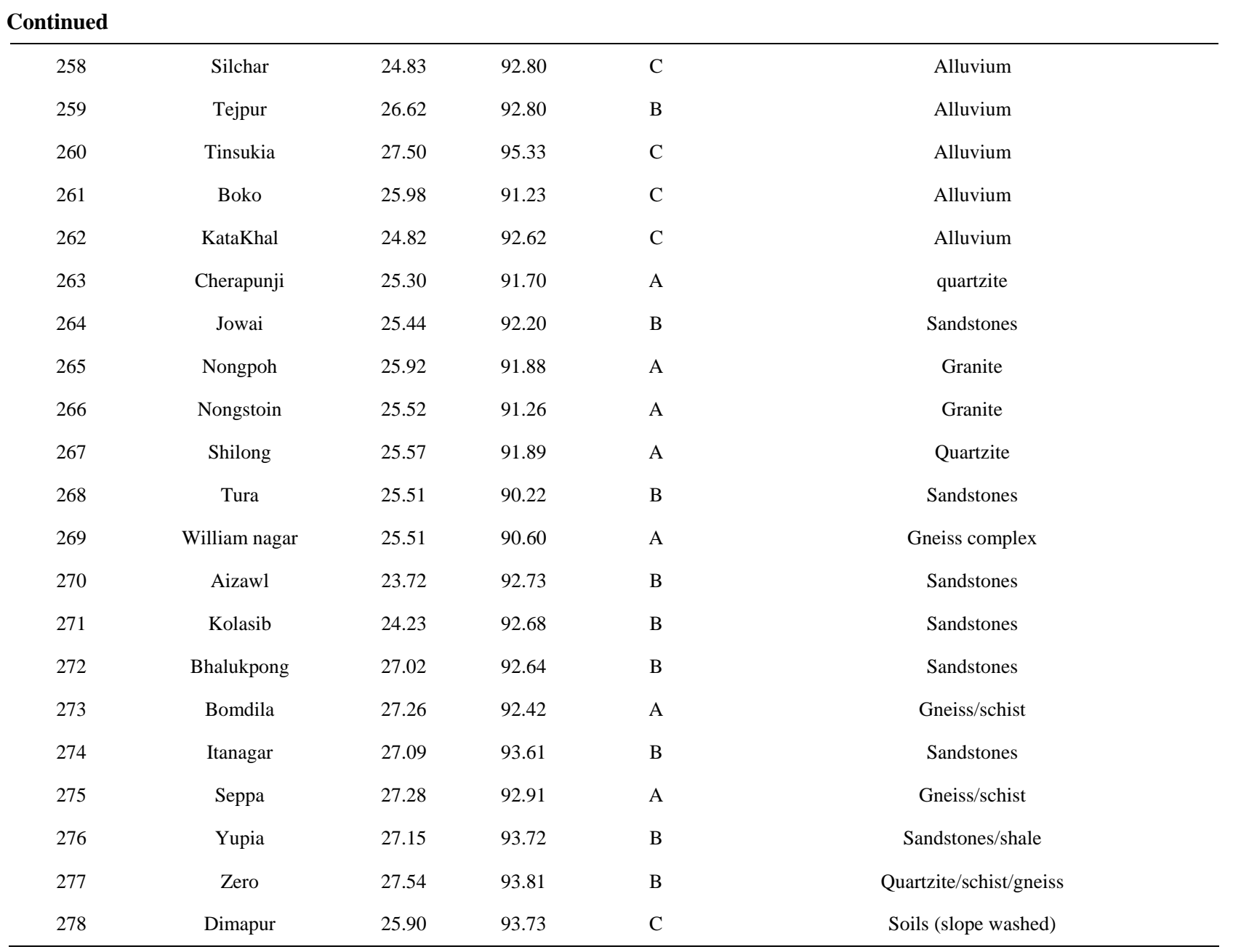




\section{Appendix 2}

List of strong motion accelerographs (SMA) stations in Delhi with locations and site geology.

\begin{tabular}{|c|c|c|c|c|c|}
\hline Station no. & Station name & Latitude & Longitude & Site class & $\begin{array}{l}\text { Site geology according to } \\
\text { seismotectonic atlas }\end{array}$ \\
\hline 1 & ANDC, Govindpuri & 28.54 & 77.26 & $\mathrm{C}$ & Alluvium \\
\hline 2 & DCE, Bawana Road & 28.80 & 77.12 & $\mathrm{C}$ & Alluvium \\
\hline 3 & University of Delhi & 28.69 & 77.21 & $\mathrm{C}$ & Alluvium \\
\hline 4 & Dhaula Kuan & 28.59 & 77.17 & $\mathrm{C}$ & Alluvium \\
\hline 5 & Raja Garden & 28.66 & 77.12 & $\mathrm{C}$ & Alluvium \\
\hline 6 & Indraprastha University & 28.66 & 77.23 & $\mathrm{C}$ & Alluvium \\
\hline 7 & IGNOU & 28.49 & 77.20 & $\mathrm{C}$ & Alluvium \\
\hline 8 & DJB, Karol Bagh & 28.65 & 77.19 & A & Quartzite \\
\hline 9 & Alipur & 28.80 & 77.14 & $\mathrm{C}$ & Alluvium \\
\hline 10 & Jamia Millia Islamia & 28.53 & 77.27 & $\mathrm{C}$ & Alluvium \\
\hline 11 & IIT Delhi & 28.55 & 77.19 & $\mathrm{C}$ & Alluvium \\
\hline 12 & JNU & 28.54 & 77.17 & A & Quartzite \\
\hline 13 & NSIT, Dwarka. & 28.61 & 77.04 & $\mathrm{C}$ & Alluvium \\
\hline 14 & $\begin{array}{c}\text { Maharaja Agrasen College, Mayur } \\
\text { Vihar }\end{array}$ & 28.60 & 77.30 & $\mathrm{C}$ & Alluvium \\
\hline 15 & IGIPE, Vikas Puri & 28.63 & 77.07 & $\mathrm{C}$ & Alluvium \\
\hline 16 & Jafarpur Kala & 28.59 & 76.91 & $\mathrm{C}$ & Alluvium \\
\hline 17 & Zakir Hussain College & 28.64 & 77.23 & $\mathrm{C}$ & Alluvium \\
\hline 18 & NPTI, Badarpur & 28.51 & 77.30 & $\mathrm{C}$ & Alluvium \\
\hline 19 & Bhim Rao Ambedkar Colleger, Delhi & 28.70 & 77.29 & $\mathrm{C}$ & Alluvium \\
\hline 20 & Ridge Observatory, IMD (NDI) & 28.68 & 77.21 & A & Quartzite \\
\hline
\end{tabular}

\section{Appendix 3}

Site class for strong motion accelerographs (SMA) station by modifying [21].

\begin{tabular}{|c|c|c|}
\hline Site class & General description & Shear wave velocity \\
\hline & Firm/hard rocks & \\
\hline B & $\begin{array}{l}\text { Soft to firm rocks } \\
\text { (Sedimentary rocks e.g., sandstone, sltstone, shale, limestone). }\end{array}$ & $375 \mathrm{~m} / \mathrm{sec}-700 \mathrm{~m} / \mathrm{sec}$ \\
\hline $\mathrm{C}$ & $\begin{array}{l}\text { SOILS } \\
\text { (Alluvium, slope wash material, Aeolian). }\end{array}$ & $200 \mathrm{~m} / \mathrm{sec}-375 \mathrm{~m} / \mathrm{sec}$ \\
\hline
\end{tabular}

